\title{
ePrescribing: Reducing Costs through In-Class Therapeutic Interchange
}

Shane P. Stenner ${ }^{1}$; Rohini Chakravarthy²; Kevin B. Johnson ${ }^{3}$; William L. Miller4; Julie Olson ${ }^{4}$; Marleen Wickizer ${ }^{4}$; Nate N. Johnson; Rick Ohmer ; David R. Uskavitch ${ }^{6}$; Gordon R. Bernard7; Erin B. Neal8; Christoph U. Lehmann ${ }^{3}$

${ }^{1}$ Departments of Biomedical Informatics \& Medicine, Vanderbilt University Medical Center, Nashville, TN;

2 Vanderbilt University, Nashville, TN;

${ }^{3}$ Departments of Biomedical Informatics \& Pediatrics, Vanderbilt University Medical Center, Nashville, TN;

${ }^{4}$ Navitus Health Solutions, Madison, Wl;

${ }^{5}$ Department of Human Resources, Vanderbilt University, Nashville, TN;

${ }^{6}$ Department of Neurology, Vanderbilt University Medical Center, Nashville, TN;

7 Division of Allergy, Pulmonary, and Critical Care Medicine, Vanderbilt University Medical Center, Nashville, TN;

${ }^{8}$ Department of Pharmaceutical Services, Vanderbilt University, Nashville, TN; Vanderbilt Health Affiliated Network, Nashville, TN

\section{Keywords}

Therapeutic interchange, electronic prescribing, cost savings, electronic health record

\section{Summary}

Introduction: Spending on pharmaceuticals in the US reached \$373.9 billion in 2014. Therapeutic interchange offers potential medication cost savings by replacing a prescribed drug for an equally efficacious therapeutic alternative.

Methods: Hard-stop therapeutic interchange recommendation alerts were developed for four medication classes (HMG-CoA reductase inhibitors, serotonin receptor agonists, intranasal steroid sprays, and proton-pump inhibitors) in an electronic prescription-writing tool for outpatient prescriptions. Using prescription data from January 2012 to June 2015, the Compliance Ratio (CR) was calculated by dividing the number of prescriptions with recommended therapeutic interchange medications by the number of prescriptions with non-recommended medications to measure effectiveness. To explore potential cost savings, prescription data and medication costs were analyzed for the 45,000 Vanderbilt Employee Health Plan members.

Results: For all medication classes, significant improvements were demonstrated - the CR improved (proton-pump inhibitors 2.8 to 5.32 , nasal steroids 2.44 to 8.16 , statins 2.06 to 5.51 , and serotonin receptor agonists 0.8 to 1.52 ). Quarterly savings through the four therapeutic interchange interventions combined exceeded $\$ 200,000$ with an estimated annual savings for the health plan of $\$ 800,000$, or more than $\$ 17$ per member.

Conclusion: A therapeutic interchange clinical decision support tool at the point of prescribing resulted in increased compliance with recommendations for outpatient prescriptions while producing substantial cost savings to the Vanderbilt Employee Health Plan $-\$ 17.77$ per member per year. Therapeutic interchange rules require rational targeting, appropriate governance, and vigilant content updates.

\section{Correspondence to:}

Christoph U. Lehmann, MD

Vanderbilt University Medical Center

2525 West End Avenue, Suite 1475

Nashville, TN 37203

culehmann@gmail.com

Tel: 615-322-4071

\author{
Appl Clin Inform 2016; 7: 1168-1181 \\ https://doi.org/10.4338/ACl-2016-09-RA-0160 \\ received: September 26, 2016 \\ accepted: October 27, 2016 \\ published: December 14, 2016 \\ Citation: Stenner SP, Chakravarthy R, Johnson KB, Mil- \\ ler WL, Olson J, Wickizer M, Johnson NN, Ohmer R, Us- \\ kavitch DR, Bernard GR, Neal EB, Lehmann CU. epre- \\ scribing: reducing costs through in-class therapeutic \\ interchange. Appl Clin Inform 2016; 7: 1168-1181 \\ https://doi.org/10.4338/ACl-2016-09-RA-0160
}




\section{Introduction}

Retail prescription drug spending in the US increased by $0.4 \%$ to $\$ 263.3$ billion in 2012 [1] and by $2.5 \%$ to $\$ 271.1$ billion in 2013 [2]. According to a recent report by IMS Institute for Healthcare informatics, nominal spending on pharmaceuticals reached $\$ 373.9$ billion in 2014, an increase of $13.1 \%$. This increase is the highest since 2001, in part due to costly breakthrough medications and manufacturer price hikes $[3,4]$. Furthermore, the effect of expanding insurance coverage for prescription drugs (especially through Medicaid) as a byproduct of the Affordable Care Act contributed to spending on drugs [5].

Poor medication adherence is involved in 33 to 69 percent of all hospital admissions, resulting in costs of $\$ 100$ billion annually, in addition to direct costs related to drugs [6]. One factor that contributes to non-adherence is the out-of-pocket costs of prescription medications. US adults are more likely than adults in nine other industrialized countries to not fill a prescription, to skip doses due to cost, and to spend more than $\$ 1,000$ out of pocket in the last year [7]. While prescribers' decisions affect how $90 \%$ of every healthcare dollar is spent [8], prescribers routinely fail to consider prescription drug and out-of-pocket costs when making decisions on expensive medical services such as prescription medications [9].

Mechanisms to reduce prescription drug costs to both patients and the health care system include therapeutic interchange or therapeutic substitution and generic substitution. ( $>$ Table 1$)$. Therapeutic interchange replaces one drug "for another drug within the same therapeutic class (e.g., benazepril for lisinopril, or ranitidine for famotidine)" or from a different class "but with a similar pharmacological effect and potency (e.g., lisinopril for amlodipine)" [10]. By definition, therapeutic interchange requires prescriber authorization or defined policies and procedures [10]. In contrast, therapeutic substitution is markedly different from therapeutic interchange. This strategy occurs without the prior authorization of the initial prescriber. "The use of therapeutic substitution is rare" and should "never be accepted unless reviewed and approved by the healthcare team based on the science available" [10]. Generic substitution substitutes a brand name drug with a generic equivalent which is identical to a "brand name drug in dosage form, safety, strength, route of administration, quality, performance characteristics and intended use" $[11,12]$. Therapeutic substitution and interchange, as well as strategies such as changing the route of a medication from intravenous to oral [13], and antimicrobial stewardship programs may be used in cost saving efforts $[14,15,16]$.

Cost savings or potential cost savings related to therapeutic interchange and substitution vary from less than $\$ 10,000$ to millions of dollars, depending on the drug class and the intervention type and scale [17]. Establishing the interchangeability of drugs may be challenging [18] because some therapeutic equivalent agents may not carry all the same indications for which the reference drug is approved. Nonetheless, 11 drug classes frequently are targeted for therapeutic interchange or substitution. Histamine $\mathrm{H} 2$-receptor antagonists, proton-pump inhibitors, antacids, and quinolones have historically been the most commonly substituted classes [19].

Therapeutic interchange policies exist in most hospitals (87\%) [20]. A recent study showed prescribing adherence improved with alerts displayed for intranasal steroid, nonbarbiturate sedatives, and hypnotics during the inpatient ordering process [21]. Evidence suggests that to date, cost-saving measures such as therapeutic interchange have not been effective in outpatient settings [22]. However, these studies have not focused on specific clinical decision support methods to alert prescribers. Previous studies using clinical decision support have demonstrated improvement in generic substitution [23]. We hypothesized that a similar approach might influence therapeutic interchange. The purpose of this study was to examine the impact of therapeutic interchange alerts on the drug ordering behavior and the costs.

\section{Methods}

Vanderbilt University collaborated with Navitus Health Solutions (Navitus), the pharmacy benefit manager for the Vanderbilt Employee Health Plan (VeHP) - Vanderbilt University Medical Center's (VUMC) self-insured health plan with 45,000 members - to determine opportunities to encourage lower cost prescribing using VUMC's electronic prescribing tool. Based on spending and utilization 
analysis, four medication classes for therapeutic interchange were selected: HMG-CoA reductase inhibitors (-statins) indicated for lowering cholesterol, serotonin receptor agonists (-triptans) for treating migraines, intranasal steroid sprays for allergic rhinitis, and proton-pump inhibitors for treating gastro-esophageal reflux and gastric ulcers. The algorithms for the therapeutic interchange were developed and validated with subject matter experts, pharmacists, nurses, and physicians and reviewed by the institution's Pharmacy and Therapeutics committee. Rules included eligibility criteria for patients ( $\geq 18$ years of age for statins and nasal steroids, $\geq 12$ years of age for triptans and proton-pump inhibitors [Age limitations were introduced to avoid the need for age-based or weight-based dosing recommendations]), non-preferred trigger medications, and therapeutic interchange medication. For the statins only, specific dosages of the non-preferred medications were linked directly to the equipotent doses of the therapeutic interchange medication ( $>$ Table 2 ).

The study utilized a locally developed electronic prescription-writing tool, called RxStar that is fully integrated into the electronic health record. RxStar is used to create outpatient prescriptions that are electronically submitted, faxed to a pharmacy, or printed on tamper-proof paper. RxStar supports common clinical decision support features such as basic formulary and benefit checking, weight-based dosing for pediatrics, dose-limit checking, drug allergy warnings, drug-drug interaction warnings, geriatric precaution warnings, and other warnings. Minimally intrusive generic substitution decision support in RxStar displays generic medication names in a large, bold font, above branded names in medication search results. This aesthetic feature of the tool has been shown to increase prescribing of generic medications [23]. RxStar also uses a centralized Clinical Decision Support (CDS) infrastructure called RxAdvisor, which may fire rules stored in a rules engine ( $>$ Figure $1)$.

We implemented the intervention in RxStar with an interruptive alert design. If any non-preferred medication was ordered for a patient meeting eligibility criteria, a pop-up alert proposed a therapeutic interchange. This alert forced a hard stop that required the prescriber to address it before proceeding. The alert informed the prescribers that the VUMC Pharmacy and Therapeutics (P\&T) Committee recommended the interchange to reduce costs ( $>$ Figure 2 ).

If the prescriber indicated that $\mathrm{s} /$ he did not agree to a therapeutic interchange, $\mathrm{s} / \mathrm{he}$ would be able to continue prescribing the originally selected medication by checking a checkbox ("Continue with [non-preferred medication] prescription") and selecting "Continue." Alternatively, the prescriber could choose to go back to the medication selection ("Cancel"). If s/he agreed to the exchange, s/he would select from one or multiple therapeutic interchange options and proceed to prescribe ("Continue"). In the event of multiple potential therapeutic interchange options, the decision support frequently (when a rule was available) preselected a medication and dose that the prescriber could override. To permit transparency of conducted work, prescriptions created by a nurse on behalf of a prescriber and forwarded to the prescriber for review explicitly stated that a therapeutic interchange had taken place.

In January 2013, we implemented the clinical decision support for the therapeutic interchange of proton-pump inhibitors. We chose proton-pump inhibitors (PPI) as a therapeutic class to test feasibility and the impact of the alerts on prescriber behavior because PPIs are a moderate cost class that constitutes a high volume of prescribing. In July 2013, we implemented interchanges for nasal steroids, triptans, and statins. VUMC notified all prescribers of the therapeutic interchange decision support at the time of the intervention go-live via a one-time screen pop-up.

All prescription data from January 2012 to June 2015 were analyzed. Prescriptions for PPIs written from January 2012 to December 2012 and all prescriptions for nasal steroids, statins, and triptans from January 2012 to June 2013 were considered Pre-Implementation, while all PPI prescriptions from January 2013 on and all other prescriptions from July 2013 on were considered in the Post-Implementation phase. We determined for the pre-, post-, and combined periods the number of prescriptions, unique providers, and unique patients.

For all patients seen at VUMC, we used Compliance Ratio (CR) and percent of prescriptions using recommended medications as measures of effectiveness of the therapeutic interchange alert. To explore statistical significance we employed Chi-squared tests. The CR was calculated by dividing the number of prescriptions with recommended therapeutic interchange medications by the number of prescriptions with non-recommended medications. To explore potential prescription cost savings, Navitus collected data on prescriptions written and associated cost data for VeHP pa- 
tients (subset of all patients). We calculated quarterly expenditures per patient, per prescription, and per provider and compared costs in the first quarter to the third quarter post intervention.

\section{Results}

From January 2013 to June 2015, a total of 407,845 prescriptions were written. \ Table 3 provides an overview on number of prescriptions, unique providers, unique patients, and prescriptions by provider and patient.

Prior to the proton-pump inhibitor alerts, the CR was 2.8 for proton-pump inhibitors - meaning there were approximately three recommended medication prescriptions for every one non-recommended prescription. After the alerts were implemented in January 2013, the CR increased to 5.32. (Prescriptions for interchange PPI medications increased from $74 \%$ to $84 \%, \mathrm{p}<0.001$ )

For nasal steroids, the CR increased from 2.44 to 8.16 after July 2013 and continued to improve over time with a CR of 13.84 in June 2015. (Prescriptions for interchange nasal steroids increased from $71 \%$ to $89 \%, \mathrm{p}<0.001$ )

For statins, the CR increased from 2.06 to 5.51. Similar to the nasal steroid performance, statin improvements continued over time leading to a CR of 6.3 in June 2015 (Prescriptions for interchange statins increased from $67 \%$ to $85 \%, \mathrm{p}<0.001$ ).

Triptans had the lowest CR prior to the intervention at 0.8 , which means that more non-recommended than recommended medications were prescribed. Post intervention, the CR increased to 1.52. (Prescriptions for interchange triptans increased from $44 \%$ to $60 \%, \mathrm{p}<0.001$ ) ( $\triangleright$ Figure 3 shows the percent of interchange medications based on all prescriptions).

The therapeutic interchange alerts resulted in substantial cost savings for the VeHP. \Table 4 shows the savings for each therapeutic category. While this method does not account for a change in the number of prescriptions thus providing only an estimate, we found that for the four therapeutic interchange interventions combined, the quarterly cost savings exceeded $\$ 200,000$, with an estimated annual savings for the 45,000 covered lives in the health plan of $\$ 800,000$, or more than $\$ 17$ per member. The cost per patient, per prescription, and per provider decreased with the intervention for each therapeutic category ( $\downarrow$ Table 4 ). The average quarterly savings per prescription were $\$ 3.12$ for all medications (Max $\$ 17.28$ for triptans, Min $\$ 1.23$ for statins). The quarterly cost per VeHP patient reduced from $\$ 10.48$ to $\$ 5.26$ after the intervention.

- Figure 4 displays the cost of each medication category as cost per member per quarter (Total cost of all medications in each category divided by the number of plan members). Despite the continued improvement in the percent of recommended PPIs prescribed, the cost for PPIs increased in the last quarter review reflecting an increase in the total number of prescriptions.

\section{Discussion}

Therapeutic interchange offers potential for substantial savings in medication costs but only a small percentage of the potential savings are realized in the US; contributing factors include pharmaceutical companies purchasing influence with US physicians [24], lack of expertise to develop interchange programs [25], and interruption of the physician's workflow by interchange alerts.

Past studies of prescribers' perception of therapeutic interchange demonstrated that most physicians would not cooperate with an interchange if they were not familiar with the proposed drug; only $26 \%$ of physicians would follow the interchange recommendation [26], a finding with important implications for implementing therapeutic interchange programs. Other factors that affect compliance of prescribers with a therapeutic interchange program include the placement of the alert in the workflow, prescribers' perception of who is recommending the interchange, and the effort associated with such a change [27].

We developed a clinical decision support tool that created alerts for prescribers at the point of prescribing allowing for a one click interchange. The intervention resulted in a substantial improvement in therapeutic interchange compliance by prescribers using the electronic prescribing tool at VUMC. The ratio of prescriptions with recommended therapeutic interchange medications to pre- 
scriptions with non-recommended medications improved in all categories. We observed ( $>$ Figure 3) an immediate increase in interchange medications by about $10 \%$ and a small continued effect over time. This observation may reflect prescribers becoming increasingly more familiar and comfortable with the therapeutic interchange recommendation.

For all therapeutic classes, substantial savings of cost per patient and per prescription were achieved. Similar to prior studies [17], we found the largest improvement in the intranasal steroid class for the 45,000 covered lives of VeHP. The overall intervention resulted in substantial quarterly savings of over $\$ 200,000$, translating into $\$ 4.44$ savings per member per quarter. While unlikely to be achievable, for the US population of 318.89 million, these savings would translate into $\$ 1.4$ billion per quarter or $\$ 5.7$ billion annually.

Adverse outcomes resulting from our intervention were not studied. While the interchange reduced drug costs, it may increase other costs not studied. Any medication change may confuse patients, who may stop medications with potentially serious outcomes. Future studies will need to examine this potential side-effect.

In subsequent years, the additional savings for our population could be expected to decline, as patients who underwent therapeutic interchange and tolerated the switch most likely will be continued on the drug and the pool for patients with opportunity for therapeutic interchange will decrease.

\section{Limitations}

This study has some limitations that affect generalizability.

1. Our outcomes regarding financial impact are limited to the measurable effect on the VeHP. Prescribers used RxStar for all patients seen in VUMC outpatient settings or discharged from the Emergency Department or an inpatient unit. The therapeutic interchange intervention applied to all patients regardless of their insurance status. Our data suggest that savings should be realized across the entire patient population, however, further investigation of claims data for patients outside the VeHP are necessary. Additionally, some VeHP patients may have seen prescribers, who do not use RxStar, leading to underestimated potential savings.

2. Data collection and analysis were limited to those prescriptions generated within RxStar. We were unable to include prescriptions that were hand-written or called-in limiting the generalizability of our findings. For convenience reasons, a comparison of the first and the third quarter cost data were conducted. Particularly, intranasal steroids may be prescribed at different rates based on the season. However, adjusting the cost per prescription still showed significant savings.

3. Our study utilized a pre/post design, which is not as strong as a randomized control trial. Future therapeutic interchange evaluation should include consideration for a prospective randomized controlled trial.

4. Similar to other therapeutic interchange efforts $[28,29]$, interchange rules were developed by a multidisciplinary team based on relevant literature and then reviewed by a P\&T committee, yet did not receive further external validation.

5. Additional limitations included concurring events such as formulary changes in a health plan. During the study period, several of the brand name triptans and nasal steroids were removed from the VeHP formulary. These changes likely had a significant impact on the overall observed cost savings making it difficult to discern the cost savings directly attributable to the RxStar alerts.

6. Costs of medications change frequently, and a therapeutic interchange program requires constant monitoring of drug cost and availability. In our study, the cost for PPIs per member increased in the second quarter of 2014. This was triggered by a shortage of pantoprazole resulting in more costly alternatives. Any interchange program requires constant vigilance to compare costs and modify substitution recommendations on current market forces. Generic medications may become more costly than brand-name medications or new generic options may become available requiring table-based rules that can be quickly revised to incorporate new recommendations. 


\section{Conclusion}

We successfully implemented a therapeutic interchange clinical decision support tool at the point of prescribing. Prescribing behavior changed favorably, as demonstrated by increased compliance with the recommended medications as measured by higher compliance ratios. Cost savings to the VeHP were substantial with $\$ 17.77$ per member per year realized. Therapeutic interchange rules require rational targeting, appropriate governance, and vigilant updates.

\section{Multiple Choice Questions}

\section{Question 1}

At the point of prescribing, the use of a pop-up for therapeutic interchange recommendation was most strongly associated with an increase in the:

A - Compliance ratio for all drug classes studied

B - Prescription cost per patient for all drug classes

C - Physician satisfaction with alerts and reminders

$\mathrm{D}$ - Increases in the use of brand name medication

\section{Correct Answer}

A - Compliance ratio for all drug classes studied

\section{Discussion}

For all medication classes the use of recommendations for therapeutic interchange resulted in significant improvements - the compliance ratio (CR) improved for proton-pump inhibitors, nasal steroids, statins, and serotonin receptor agonists. Prescription costs decreased with quarterly savings through the four therapeutic interchange interventions combined exceeding \$200,000 with an estimated annual savings for the health plan of $\$ 800,000$, or more than $\$ 17$ per member.

\section{Question 2}

The mechanism by which a prescribed drug is exchanged with prescriber authorization or by policy for an alternative agent with a different chemical composition that acts in a therapeutically equivalent manner is called
A - Generic substitution
B - Generic stewardship
C - Therapeutic substitution
$\mathrm{D}$ - Therapeutic interchange

\section{Correct Answer}

D - Therapeutic interchange

\section{Discussion}

Therapeutic substitution is the mechanism by which a prescribed drug is exchanged without prescriber authorization for an alternative agent with a different chemical composition that acts in a therapeutically equivalent manner. Therapeutic interchange is the mechanism by which a prescribed drug is exchanged with prescriber authorization or by policy for an alternative agent with a different chemical composition that acts in a therapeutically equivalent manner. In generic substitution, a brand name drug is substituted with a generic equivalent, which is identical to a "brand name drug in dosage form, safety, strength, route of administration, quality, performance characteristics and intended use." Stewardship programs use the need to obtain permissions to reduce the prescribing of certain medications. 


\section{Clinical Relevance Statement}

A therapeutic interchange clinical decision support tool at the point of prescribing changed provider behavior favorably and resulted in increased compliance with recommended medications and substantial cost savings.

\section{Conflict of Interest}

The authors work for Vanderbilt University or Navitus. They have no other conflicts of interest.

\section{Protection of Human and Animal Subjects}

The study was performed in compliance with the World Medical Association Declaration of Helsinki on Ethical Principles for Medical Research Involving Human Subjects. 


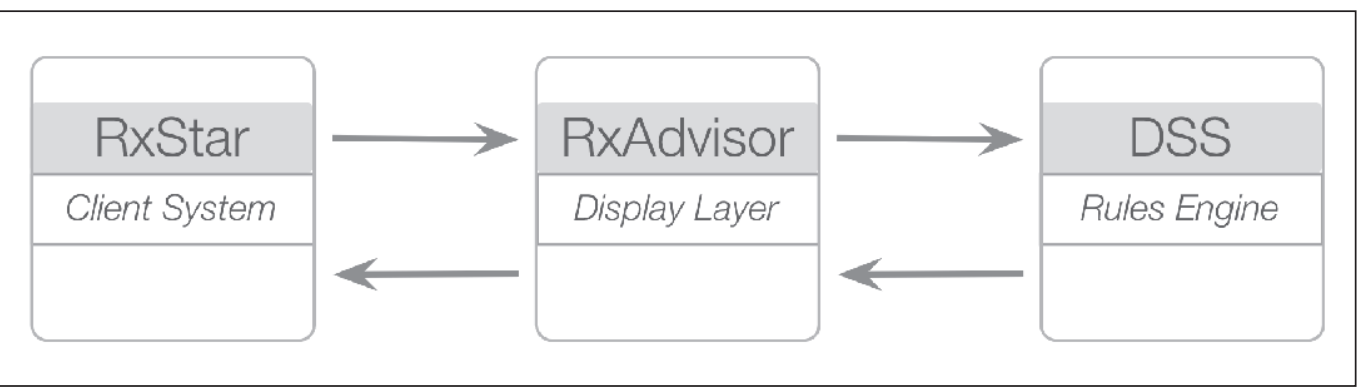

Fig. 1 Centralized CDS model for RxStar (DSS = Decision Support System)

\section{Therapeutic Alternative Advisor}

Generic in-class substitution recommended due to cost savings

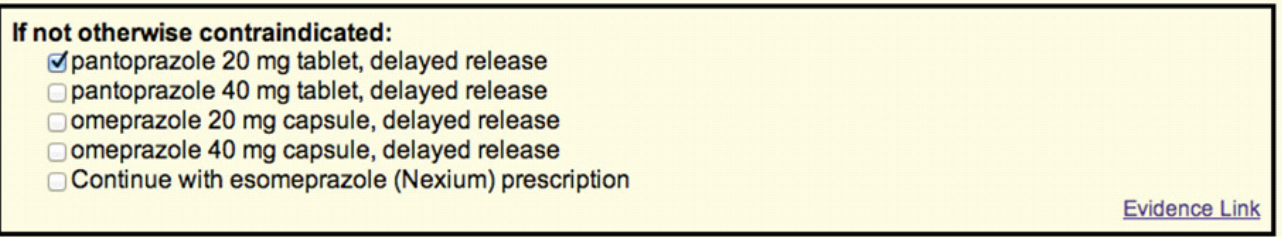

The Vanderbilt Pharmacy and Therapeutics Committee recommends that pantoprazole or omeprazole replace branded proton pump inhibitors which can cost as much as \$6 more per dose or \$2,190 more per year. In-class generic substitutes are equally efficacious in most clinical scenarios.

Fig. 2 Example of a therapeutic interchange alert

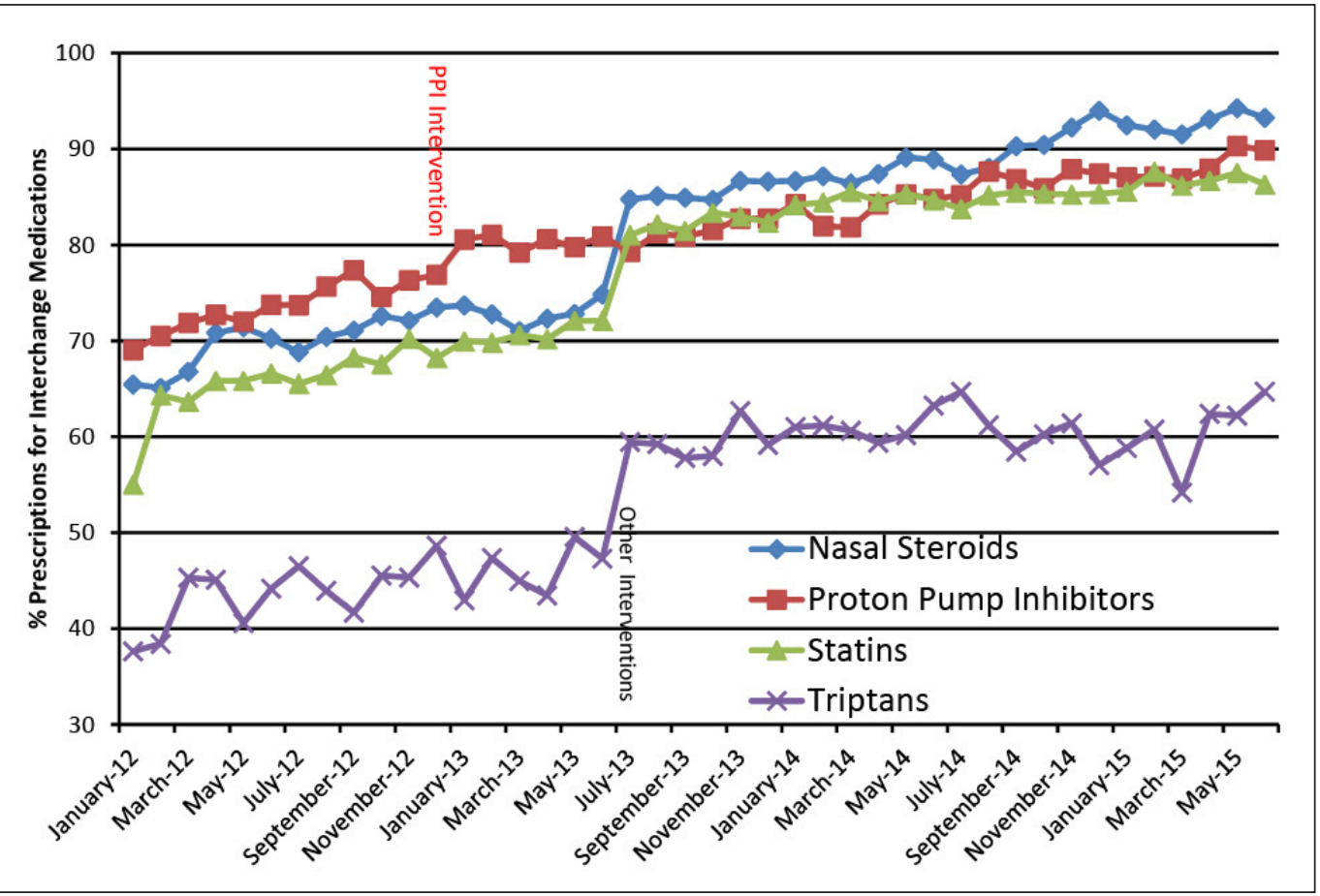

Fig. 3 Interchange medication prescriptions 


\section{Research Article}

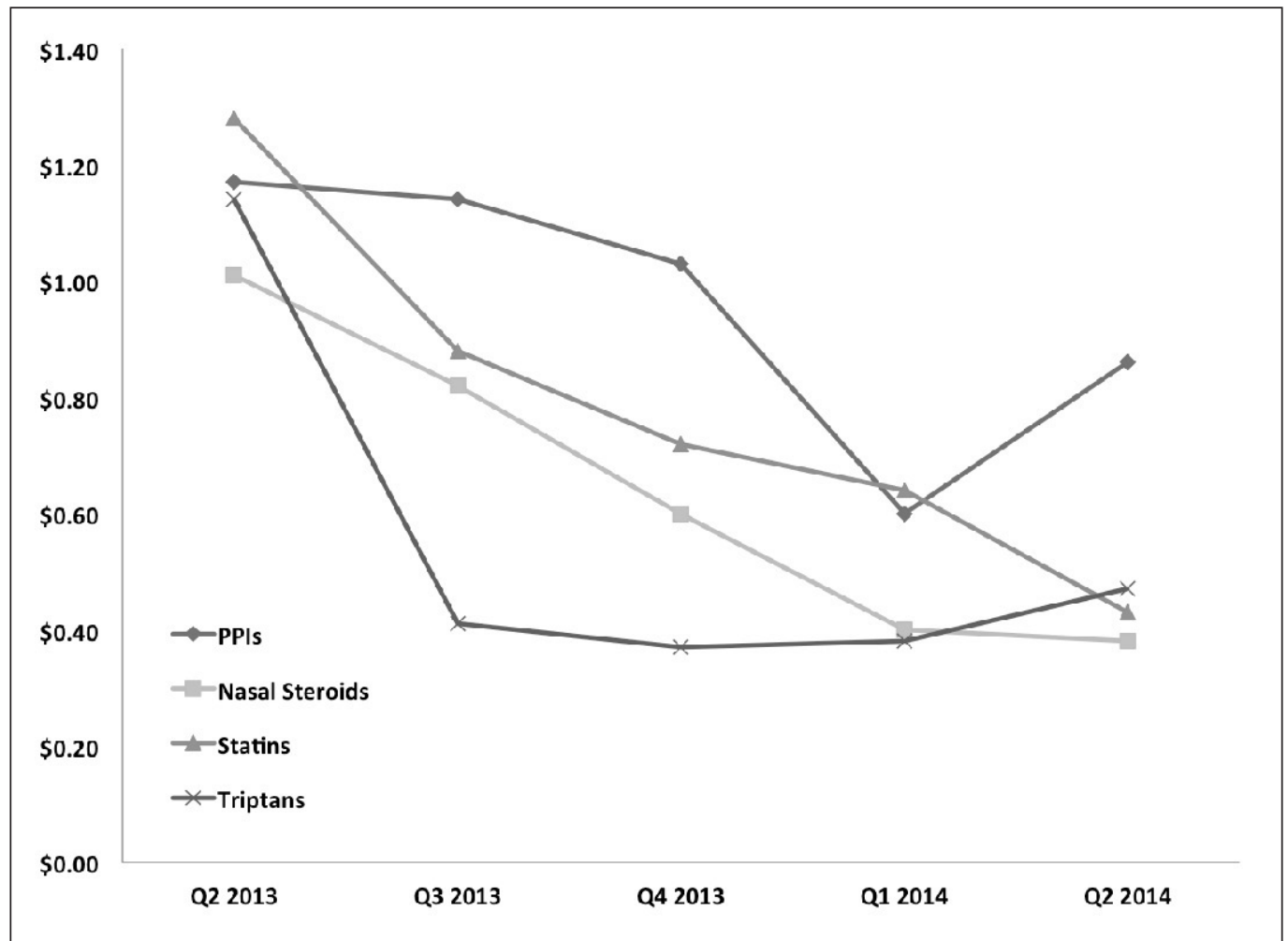

Fig. 4 Cost per member per quarter based on therapeutic class 
Table 1 Mechanisms to reduce prescription drug costs

\begin{tabular}{|l|l|l|l|}
\hline Approach & Description & Drug Chemical & $\begin{array}{l}\text { Prescriber } \\
\text { authorization }\end{array}$ \\
\hline $\begin{array}{l}\text { Generic substi- } \\
\text { tution }\end{array}$ & $\begin{array}{l}\text { Replaces the drug brand pre- } \\
\text { scribed with a different brand or } \\
\text { an unbranded drug }\end{array}$ & $\begin{array}{l}\text { Same chemical as the pre- } \\
\text { scribed medication }\end{array}$ & Not required \\
\hline $\begin{array}{l}\text { Therapeutic sub- } \\
\text { stitution }\end{array}$ & $\begin{array}{l}\text { Replaces the prescribed drug for } \\
\text { an alternative agent with a dif- } \\
\text { ferent chemical composition }\end{array}$ & $\begin{array}{l}\text { Different chemical but acts } \\
\text { therapeutically in an equival- } \\
\text { ent manner }\end{array}$ & Not required \\
\hline $\begin{array}{l}\text { Therapeutic In- } \\
\text { terchange }\end{array}$ & $\begin{array}{l}\text { Replaces the prescribed drug for } \\
\text { an alternative agent with a dif- } \\
\text { ferent chemical composition }\end{array}$ & $\begin{array}{l}\text { Different chemical but acts } \\
\text { therapeutically in an equival- } \\
\text { ent manner }\end{array}$ & $\begin{array}{l}\text { Required (may be performed } \\
\text { without approval according } \\
\text { to the policies and procedur- } \\
\text { es of an oversight body) }\end{array}$ \\
\hline
\end{tabular}

Table 2 Therapeutic Interchange rules

\begin{tabular}{|c|c|c|}
\hline Trigger(s) & Recommended & Pre-checked \\
\hline \multicolumn{3}{|l|}{ Statins } \\
\hline Crestor 40 mg tablet & atorvastatin $80 \mathrm{mg}$ tablet & $x$ \\
\hline Crestor $20 \mathrm{mg}$ tablet & atorvastatin $40 \mathrm{mg}$ tablet & $x$ \\
\hline $\begin{array}{l}\text { Crestor } 10 \mathrm{mg} \text { tablet } \\
\text { Livalo } 4 \mathrm{mg} \text { tablet }\end{array}$ & $\begin{array}{l}\text { atorvastatin } 20 \mathrm{mg} \text { tablet } \\
\text { simvastatin } 40 \mathrm{mg} \text { tablet } \\
\text { pravastatin } 80 \mathrm{mg} \text { tablet }\end{array}$ & $x$ \\
\hline $\begin{array}{l}\text { Crestor } 5 \mathrm{mg} \text { tablet } \\
\text { Livalo } 2 \mathrm{mg} \text { tablet }\end{array}$ & $\begin{array}{l}\text { atorvastatin } 10 \mathrm{mg} \text { tablet } \\
\text { simvastatin } 20 \mathrm{mg} \text { tablet } \\
\text { pravastatin } 40 \mathrm{mg} \text { tablet }\end{array}$ & $x$ \\
\hline Livalo 1 mg tablet & $\begin{array}{l}\text { pravastatin } 20 \mathrm{mg} \text { tablet } \\
\text { simvastatin } 10 \mathrm{mg} \text { tablet }\end{array}$ & $x$ \\
\hline Pravachol $80 \mathrm{mg}$ tablet & pravastatin $80 \mathrm{mg}$ tablet & $x$ \\
\hline Pravachol 40 mg tablet & pravastatin $40 \mathrm{mg}$ tablet & $x$ \\
\hline Pravachol $20 \mathrm{mg}$ tablet & pravastatin $20 \mathrm{mg}$ tablet & $x$ \\
\hline Lipitor 80 mg tablet & atorvastatin $80 \mathrm{mg}$ tablet & $x$ \\
\hline Lipitor 40 mg tablet & atorvastatin $40 \mathrm{mg}$ tablet & $x$ \\
\hline Lipitor $20 \mathrm{mg}$ tablet & atorvastatin $20 \mathrm{mg}$ tablet & $x$ \\
\hline Lipitor 10 mg tablet & atorvastatin $10 \mathrm{mg}$ tablet & $x$ \\
\hline \multicolumn{3}{|l|}{ Triptans } \\
\hline $\begin{array}{l}\text { Axert } 6.25 \mathrm{mg} \text { tablet } \\
\text { Axert } 12.5 \mathrm{mg} \text { tablet } \\
\text { Maxalt } 5 \mathrm{mg} \text { tablet } \\
\text { Maxalt } 10 \mathrm{mg} \text { tablet } \\
\text { Maxalt-MLT } 5 \mathrm{mg} \text { disintegrating tablet } \\
\text { Maxalt-MLT } 10 \mathrm{mg} \text { disintegrating tablet } \\
\text { Relpax } 20 \mathrm{mg} \text { tablet } \\
\text { Relpax } 40 \mathrm{mg} \text { tablet } \\
\text { Zomig } 2.5 \mathrm{mg} \text { tablet } \\
\text { Zomig } 5 \mathrm{mg} \text { tablet } \\
\text { Zomig ZMT } 2.5 \mathrm{mg} \text { disintegrating tablet } \\
\text { Zomig ZMT } 5 \mathrm{mg} \text { disintegrating tablet }\end{array}$ & $\begin{array}{l}\text { sumatriptan } 25 \mathrm{mg} \text { tablet } \\
\text { sumatriptan } 50 \mathrm{mg} \text { tablet } \\
\text { sumatriptan } 100 \mathrm{mg} \text { tablet }\end{array}$ & \\
\hline
\end{tabular}


Table 2 Continued

\begin{tabular}{|c|c|c|}
\hline Trigger(s) & Recommended & Pre-checked \\
\hline \multicolumn{3}{|l|}{ Triptans } \\
\hline \multicolumn{3}{|l|}{$\begin{array}{l}\text { Imitrex } 25 \mathrm{mg} \text { tablet } \\
\text { Imitrex } 50 \mathrm{mg} \text { tablet } \\
\text { Imitrex } 100 \mathrm{mg} \text { tablet } \\
\text { rizatriptan } 5 \mathrm{mg} \text { tablet } \\
\text { rizatriptan } 10 \mathrm{mg} \text { tablet } \\
\text { rizatriptan } 5 \mathrm{mg} \text { disintegrating tablet } \\
\text { rizatriptan } 10 \mathrm{mg} \text { disintegrating tablet }\end{array}$} \\
\hline $\begin{array}{l}\text { Frova } 2.5 \mathrm{mg} \text { tablet } \\
\text { Amerge } 1 \mathrm{mg} \text { tablet } \\
\text { Amerge } 2.5 \mathrm{mg} \text { tablet }\end{array}$ & $\begin{array}{l}\text { naratriptan } 1 \mathrm{mg} \text { tablet } \\
\text { naratriptan } 2.5 \mathrm{mg} \text { tablet }\end{array}$ & \\
\hline $\begin{array}{l}\text { Zomig nasal spray } \\
\text { Maxalt nasal spray } \\
\text { Imitrex nasal spray }\end{array}$ & $\begin{array}{l}\text { sumatriptan } 5 \mathrm{mg} \text { nasal spray } \\
\text { sumatriptan } 10 \mathrm{mg} \text { nasal spray }\end{array}$ & \\
\hline \multicolumn{3}{|l|}{ Proton-Pump Inhibitors } \\
\hline $\begin{array}{l}\text { Nexium } 20 \mathrm{mg} \text { tablet } \\
\text { Nexium } 40 \mathrm{mg} \text { tablet } \\
\text { Aciphex } 20 \mathrm{mg} \text { tablet } \\
\text { Dexilant } 30 \mathrm{mg} \text { tablet } \\
\text { Dexilant } 60 \mathrm{mg} \text { tablet } \\
\text { Nexium Packet } 10 \mathrm{mg} \text { oral suspension } \\
\text { Nexium Packet } 20 \mathrm{mg} \text { oral suspension } \\
\text { Nexium Packet } 40 \mathrm{mg} \text { oral suspension }\end{array}$ & $\begin{array}{l}\text { pantoprazole } 20 \mathrm{mg} \text { tablet } \\
\text { pantoprazole } 40 \mathrm{mg} \text { tablet } \\
\text { omeprazole } 20 \mathrm{mg} \text { tablet } \\
\text { omeprazole } 40 \mathrm{mg} \text { tablet }\end{array}$ & $x$ \\
\hline \multicolumn{3}{|l|}{ Nasal Steroids } \\
\hline $\begin{array}{l}\text { Beconase AQ } 42 \mathrm{mcg}(0.042 \%) \text { nasal spray } \\
\text { QNASL } 80 \mathrm{mcg} / \text { actuation nasal HFA inhaler } \\
\text { Rhinocort } 32 \mathrm{mcg} / \text { actuation nasal spray } \\
\text { Veramyst } 27.5 \mathrm{mcg} / \text { actuation nasal spray } \\
\text { Nasonex } 50 \mathrm{mcg} / \text { actuation spray } \\
\text { Omnaris } 50 \mathrm{mcg} \text { nasal spray } \\
\text { Zetonna } 37 \mathrm{mcg} / \text { actuation nasal HFA inhaler } \\
\text { Nasacort AQ } 55 \mathrm{mcg} \text { nasal spray aerosolflu } \\
\text { triamcinolone acetonide } 55 \text { mcg nasal spray aerosol } \\
\text { Flonase } 50 \mathrm{mcg} / \text { actuation nasal spray }\end{array}$ & $\begin{array}{l}\text { fluticasone } 50 \text { mcg/actuation } \\
\text { nasal spray, susp }\end{array}$ & \\
\hline
\end{tabular}

Table 3 Number of prescriptions, unique providers, unique patients as well as prescriptions per provider and patient

\begin{tabular}{|l|l|c|r|r|r|}
\hline & All Rx & Nasal Steroids & PPIs & Statins & Triptans \\
\hline $\begin{array}{l}\text { Unique Prescriptions } \\
\text { Pre intervention }\end{array}$ & 142175 & 53955 & 25007 & 55736 & 7477 \\
\hline Post Intervention & 265670 & 83523 & 82887 & 85464 & 13796 \\
\hline Combined Periods & 407845 & 137478 & 107894 & 141200 & 21273 \\
\hline Unique Providers & & & & & \\
\hline Pre intervention & 1435 & 847 & 1026 & 684 & 462 \\
\hline Post Intervention & 1921 & 1104 & 1666 & 880 & 599 \\
\hline
\end{tabular}


Table 3 Continued

\begin{tabular}{|l|c|c|c|c|c|}
\hline & All Rx & Nasal Steroids & PPIs & Statins & Triptans \\
\hline Combined Periods & 2264 & 1370 & 1913 & 1112 & 780 \\
\hline Unique Patients & & & & & \\
\hline Pre intervention & 68987 & 33646 & 15939 & 26880 & 4230 \\
\hline Post Intervention & 98741 & 45450 & 34111 & 33457 & 6065 \\
\hline Combined Periods & 126679 & 65114 & 40943 & 41293 & 8116 \\
\hline Rxs per Provider & & & & & \\
\hline Pre intervention & 99.1 & 63.7 & 24.4 & 81.5 & 16.2 \\
\hline Post Intervention & 138.3 & 75.7 & 49.8 & 97.1 & 23.0 \\
\hline Combined Periods & 180.1 & 100.3 & 56.4 & 127.0 & 27.3 \\
\hline Rxs per Patient & & & & & \\
\hline Pre intervention & 2.1 & 1.6 & 1.6 & 2.1 & 1.8 \\
\hline Post Intervention & 2.7 & 1.8 & 2.4 & 2.6 & 2.3 \\
\hline Combined Periods & 3.2 & 2.1 & 3.4 & 2.6 \\
\hline
\end{tabular}

Table 4 Cost savings by drug class

\begin{tabular}{|c|c|c|c|c|}
\hline $\begin{array}{l}\text { Therapeutic } \\
\text { Categories }\end{array}$ & Costs & Original cost Q1 & $\begin{array}{l}\text { Cost post } \\
\text { Therapeutic } \\
\text { Interchange Q3 }\end{array}$ & Savings \\
\hline \multirow[t]{4}{*}{ Statins } & Total Quarterly Cost & $\$ 148,372$ & $\$ 122,525$ & $\$ 25,847$ \\
\hline & Cost per Patient & $\$ 5.52$ & $\$ 3.66$ & $\$ 1.86$ \\
\hline & Cost per Prescription & $\$ 2.66$ & $\$ 1.43$ & $\$ 1.23$ \\
\hline & Cost per Provider & $\$ 216.92$ & $\$ 139.23$ & $\$ 77.69$ \\
\hline \multirow[t]{4}{*}{ Triptans } & Total Quarterly Cost & $\$ 166,034$ & $\$ 68,000$ & $\$ 98,034$ \\
\hline & Cost per Patient & $\$ 39.25$ & $\$ 11.21$ & $\$ 28.04$ \\
\hline & Cost per Prescription & $\$ 22.21$ & $\$ 4.93$ & $\$ 17.28$ \\
\hline & Cost per Provider & $\$ 359.38$ & $\$ 113.52$ & $\$ 245.86$ \\
\hline \multirow[t]{4}{*}{ Nasal Steroids } & Total Quarterly Cost & $\$ 214,641$ & $\$ 155,465$ & $\$ 59,176$ \\
\hline & Cost per Patient & $\$ 6.38$ & $\$ 1.86$ & $\$ 4.52$ \\
\hline & Cost per Prescription & $\$ 3.98$ & $\$ 1.86$ & $\$ 2.12$ \\
\hline & Cost per Provider & $\$ 253.41$ & $\$ 140.82$ & $\$ 112.59$ \\
\hline \multirow{4}{*}{$\begin{array}{l}\text { Proton-pump } \\
\text { Inhibitor }\end{array}$} & Total Quarterly Cost & $\$ 193,713$ & $\$ 173,531$ & $\$ 20,182$ \\
\hline & Cost per Patient & $\$ 12.15$ & $\$ 5.09$ & $\$ 7.07$ \\
\hline & Cost per Prescription & $\$ 7.75$ & $\$ 2.09$ & $\$ 5.66$ \\
\hline & Cost per Provider & $\$ 188.80$ & $\$ 104.16$ & $\$ 84.64$ \\
\hline \multirow[t]{4}{*}{ Total } & Total Quarterly Cost & $\$ 722,760$ & $\$ 519,521$ & $\$ 203,239$ \\
\hline & Cost per Patient & $\$ 10.48$ & $\$ 5.26$ & $\$ 5.22$ \\
\hline & Cost per Prescription & $\$ 5.08$ & $\$ 1.96$ & $\$ 3.12$ \\
\hline & Cost per Provider & $\$ 503.67$ & $\$ 270.44$ & $\$ 233.23$ \\
\hline
\end{tabular}




\section{References}

1. Centers for Medicare and Medicaid Services. National Health Expenditures 2012 Highlights. Available online at https://www.cms.gov/Research-Statistics-Data-and-Systems/Statistics-Trends-and-Reports/ NationalHealthExpendData/downloads/highlights.pdf. Last accessed May 10, 2015.

2. Centers for Medicare and Medicaid Services. National Health Expenditures 2013 Highlights. Available online at http://www.cms.gov/Research-Statistics-Data-and-Systems/Statistics-Trends-and-Reports/ NationalHealthExpendData/Downloads/highlights.pdf. Last accessed May 10, 2015.

3. IMS Institute for Healthcare Informatics. Medicines Use and Spending Shifts: A Review of the Use of Medicines in the U.S. in 2014. Available online at http://www.redaccionmedica.com/contenido/images/ IIHI_Use_of_Medicines_Report_2015.pdf. Last accessed May 14, 2015.

4. Lorenzetti L. The U.S. Has the Highest Drug Prices in the World. And Hating Martin Shkreli Won' Be Enough to Change It. Fortune 2015; 172(6): 17-18. PubMed PMID: 26875209.

5. Daemmrich A, Mohanty A. Healthcare reform in the United States and China: pharmaceutical market implications. J Pharm Policy Pract 2014; 7(1): 9. doi: 10.1186/2052-3211-7-9. eCollection 2014. PubMed PMID: 25097759; PubMed Central PMCID: PMC4117976.

6. Osterberg L, Blaschke T. Adherence to medication. N Engl J Med 2005; 353(5): 487-497. Review. PubMed PMID: 16079372.

7. Schoen C, Osborn R, Squires D, Doty MM. Access, affordability, and insurance complexity are often worse in the United States compared to ten other countries. Health Aff (Millwood) 2013; 32(12): 2205-2215. doi: 10.1377/hlthaff.2013.0879. Epub 2013 Nov 13. PubMed PMID: 24226092.

8. Eisenberg JM. Physician utilization: the state of research about physicians' practice patterns. Med Care 2002; 40(11): 1016-1035. PubMed PMID: 12409848.

9. Pham HH, Alexander GC, O'Malley AS. Physician consideration of patients' out-of-pocket costs in making common clinical decisions. Arch Intern Med 2007; 167(7): 663-668. PubMed PMID: 17420424.

10. Gray T, Bertch K, Galt K, Gonyeau M, Karpiuk E, Oyen L, Sudekum MJ, Vermeulen LC; American College of Clinical Pharmacy. Guidelines for therapeutic interchange-2004. Pharmacotherapy 2005; 25(11): 1666-1680. PubMed PMID: 16232030.

11.U.S. Food and Drug Administration. Generic Drugs: Questions and Answers. Available online at http://www.fda.gov/Drugs/ResourcesForYou/Consumers/QuestionsAnswers/ucm100100.htm. Last accessed Jun 19, 2015.

12. Holmes DR Jr, Becker JA, Granger CB, Limacher MC, Page RL 2nd, Sila C. ACCF/AHA 2011 health policy statement on therapeutic interchange and substitution: a report of the American College of Cardiology Foundation Clinical Quality Committee. Circulation 2011; 124(11): 1290-1310. doi: 10.1161/CIR.0b013e31822d97d5. Epub 2011 Aug 15. Review. Erratum in: Circulation 2011; 124(13): e364. PubMed PMID: 21844072.

13. Lau BD, Pinto BL, Thiemann DR, Lehmann CU. Budget impact analysis of conversion from intravenous to oral medication when clinically eligible for oral intake. Clin Ther 2011; 33(11): 1792-1796. doi: 10.1016/j.clinthera.2011.09.030. PubMed PMID: 22001356.

14. Agwu AL, Lee CK, Jain SK, Murray KL, Topolski J, Miller RE, Townsend T, Lehmann CU. A World Wide Web-based antimicrobial stewardship program improves efficiency, communication, and user satisfaction and reduces cost in a tertiary care pediatric medical center. Clin Infect Dis 2008; 47(6): 747-753. doi: 10.1086/591133. PubMed PMID: 18680419.

15. Venugopal V, Lehmann CU, Diener-West M, Agwu AL. Longitudinal evaluation of a World Wide Webbased antimicrobial stewardship program: assessing factors associated with approval patterns and trends over time. Am J Infect Control 2014; 42(2): 100-105. doi: 10.1016/j.ajic.2013.09.018. PubMed PMID: 24485366.

16. Sick AC, Lehmann CU, Tamma PD, Lee CK, Agwu AL. Sustained savings from a longitudinal cost analysis of an internet-based preapproval antimicrobial stewardship program. Infect Control Hosp Epidemiol 2013; 34(6): 573-580. doi: 10.1086/670625. Epub 2013 Apr 18. PubMed PMID: 23651887.

17. Thomas L, Culley EJ, Gladowski P, Goff V, Fong J, Marche SM. Longitudinal analysis of the costs associated with inpatient initiation and subsequent outpatient continuation of proton pump inhibitor therapy for stress ulcer prophylaxis in a large managed care organization. J Manag Care Pharm 2010; 16(2): 122-129. PubMed PMID: 20178397.

18.Lucio SD, Stevenson JG, Hoffman JM. Biosimilars: Implications for health-system pharmacists. Am J Health Syst Pharm 2013; 70(22): 2004-2017. doi: 10.2146/ajhp130119. PubMed PMID: 24173009; PubMed Central PMCID: PMC4203383. 
19. Schachtner JM, Guharoy R, Medicis JJ, Newman N, Speizer R. Prevalence and cost savings of therapeutic interchange among U.S. hospitals. Am J Health Syst Pharm 2002; 59(6): 529-533. PubMed PMID: 11908245.

20. Pedersen CA, Schneider PJ, Scheckelhoff DJ. ASHP national survey of pharmacy practice in hospital settings: Prescribing and transcribing-2013. Am J Health Syst Pharm 2014; 71(11): 924-942. doi: 10.2146/ajhp140032. PubMed PMID: 24830997.

21. Helmons PJ, Coates CR, Kosterink JG, Daniels CE. Decision support at the point of prescribing to increase formulary adherence. Am J Health Syst Pharm 2015; 72(5): 408-413. doi: 10.2146/ajhp140388. PubMed PMID: 25694416.

22. Carroll NV. How effectively do managed care organizations influence prescribing and dispensing decisions? Am J Manag Care 2002; 8(12): 1041-1054. Review. PubMed PMID: 12500881.

23. Stenner SP, Chen Q, Johnson KB. Impact of generic substitution decision support on electronic prescribing behavior. J Am Med Inform Assoc 2010; 17(6): 681-688. doi: 10.1136/jamia.2009.002568. PubMed PMID: 20962131; PubMed Central PMCID: PMC3DS.

24.Loftus P. Doctors net billions from drug firms. The Wall Street Journal. Sept 30, 2014. Available online at http://www.wsj.com/articles/u-s-agency-reveals-drug-makers-payments-to-doctors-1412100323. Last accessed May 14, 2015.

25. Schumock GT, Nutescu EA, Walton SM, Arondekar BV, Lewis RK. Survey of hospital policies regarding low-molecular-weight heparins. Am J Health Syst Pharm 2002; 59(6): 534-538. PubMed PMID: 11908246.

26. Poole TA. Survey of pharmacists' and physicians' perceptions of therapeutic interchange. Adv Ther 2005; 22(1): 1-9. PubMed PMID: 15943216.

27. Miller RA, Waitman LR, Chen S, Rosenbloom ST. The anatomy of decision support during inpatient care provider order entry (CPOE): empirical observations from a decade of CPOE experience at Vanderbilt. J Biomed Inform 2005; 38(6): 469-485. PubMed PMID: 16290243; PubMed Central PMCID: PMC1518541.

28. Pruszydlo MG, Walk-Fritz SU, Hoppe-Tichy T, Kaltschmidt J, Haefeli WE. Development and evaluation of a computerised clinical decision support system for switching drugs at the interface between primary and tertiary care. BMC Med Inform Decis Mak 2012; 12: 137. doi: 10.1186/1472-6947-12-137. PubMed PMID: 23185973; PubMed Central PMCID: PMC3518241.

29. Lee YY, Hsiao P, Lin YM, Yen YH, Chen HY. Successful implementation of a P\&T-approved therapeutic interchange program of angiotensin II receptor blockers in a medical center in Taiwan. Value Health 2012; 15(1 Suppl.): S111-S115. doi: 10.1016/j.jval.2011.11.001. PubMed PMID: 2265056. 